\title{
EFFECT OF INCREASED CARBON DIOXIDE IN INSPIRED AIR ON THE MORPHOLOGY OF SPERMATOZOA AND FERTILITY OF MICE
}

\author{
D. P. MUKHERJEE and S. P. SINGH \\ Division of Animal Genetics, Indian Veterinary Research Institute, \\ Izatnagar, India
}

(Received 6th September 1965, revised 29th August 1966)

\begin{abstract}
Summary. Exposure of male mice to a $1 \cdot 8 / 1.0$ mixture of air $/ \mathrm{CO}_{2}$ for a total of $6 \mathrm{hr}$ reduced the area and breadth of the head and of the midpiece of live spermatozoa in the vasa deferentia. During a total of $26 \frac{1}{2} \mathrm{hr}$ exposure spread over 6 days, males when test-mated had a low conception rate but the numbers of offspring in the litters produced were normal. The low conception rate of males appeared to persist even 15 days after the end of treatment.
\end{abstract}

The object of the experiment was to increase $\mathrm{CO}_{2}$ (and thereby reduce oxygen) in the inspired air of male mice and to study the effect on spermatozoan morphology and fertility. The apparatus shown in Text-fig. 1 supplied an air $/ \mathrm{CO}_{2}$ mixture to an experimental chamber whose inlet was connected to the top ends of two flowmeters through one-way valves. One flowmeter was connected to a $\mathrm{CO}_{2}$ reservoir. The other and a third flowmeter were connected to an air pump. The top of the third flowmeter was connected to the inlet of the control chamber through a one-way valve. The outlets of the two chambers were fitted with one-way valves to exclude extraneous air.

Male mice (colony bred, Swiss strain), weighing between 32 and $37 \mathrm{~g}$, were allotted at random to a control and an experimental group, each of ten mice. The groups were placed in their chambers simultaneously. In the experimental chamber an air $/ \mathrm{CO}_{2}$ mixture in the proportion of $1.8 / 1.0$ by volume was supplied. In the control chamber air only was supplied, at the same flow rate as that of the mixture. The proportion of air to $\mathrm{CO}_{2}$ had been determined from preliminary work. In winter (air temperature $18^{\circ} \mathrm{C}$ ) mice survived if allowed to recuperate in air for $\frac{1}{2} \mathrm{hr}$ after each 2-hr exposure to the mixture. In summer $\left(30\right.$ to $32^{\circ} \mathrm{C}$ ) a recuperation period of $15 \mathrm{~min}$ was necessary after each hour of exposure.

After a nett exposure of $6 \mathrm{hr}$ to the mixture the treated mice (and the controls) were killed by dislocating the neck. Five permanent nigrosin-eosin slides were prepared from the mixed contents of the two vasa deferentia of each male. The 100 slides were coded and examined in randomized order. Camera lucida 
drawings of four normal unstained spermatozoa per slide were made at a linear magnification of $\times 6560$. The maximum breadth and the projected area of the spermatozoan head, and the length, breadth and projected area of the midpiece, were measured as described by Beatty \& Mukherjee (1963). In addition the percentage of unstained spermatozoa was scored from 100 spermatozoa per slide.

To test male fertility, males and virgin females, all of comparable body weight, were allotted in equal numbers to a control and an experimental

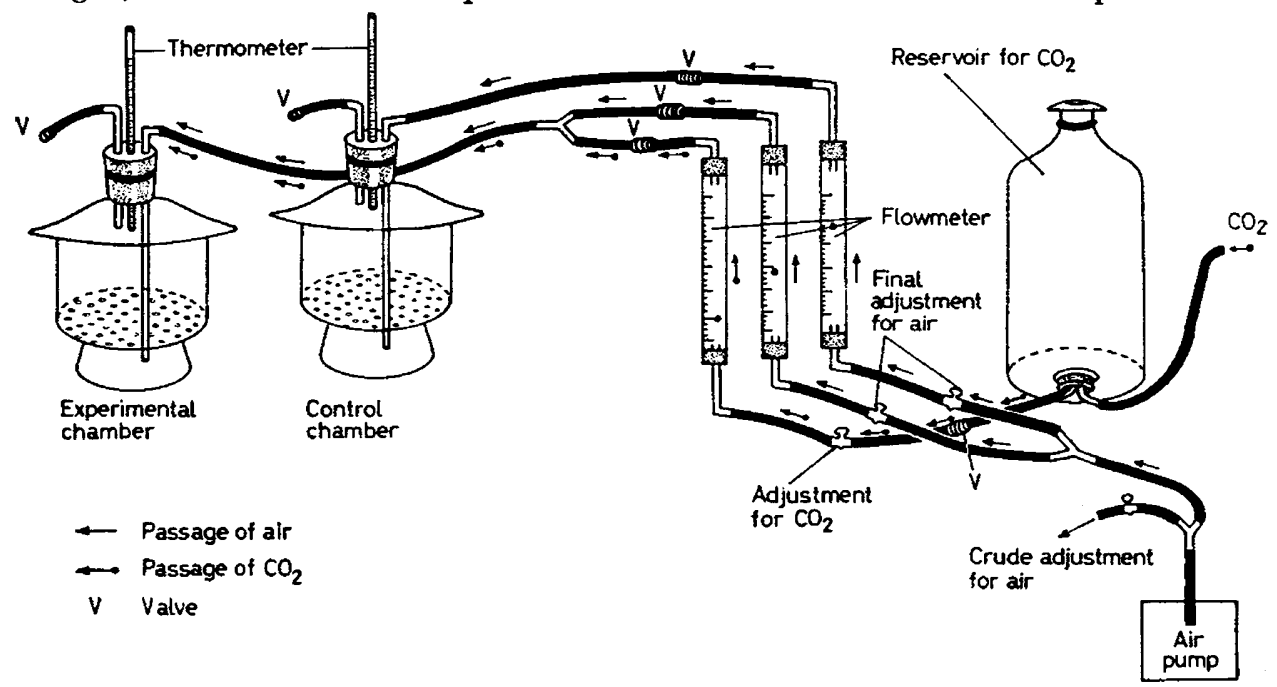

TEXT-FIG. 1. Apparatus used for changing the gaseous composition of inspired air of mice.

TABLE 1

GROUP MEANS AND ANALYSIS OF VARIANCE OF SPERMATOZOAN CHARACTERISTICS

\begin{tabular}{|c|c|c|c|c|c|c|c|}
\hline Group means & d.f. & $\begin{array}{l}\text { Head } \\
\text { area } \\
\left(\mu^{2}\right)\end{array}$ & $\begin{array}{c}\text { Head } \\
\text { breadth } \\
(\mu)\end{array}$ & $\begin{array}{c}\text { Midpiece } \\
\text { area } \\
\left(\mu^{2}\right)\end{array}$ & $\begin{array}{c}\text { Midpiece } \\
\text { length } \\
(\mu)\end{array}$ & $\begin{array}{c}\text { Midpiece } \\
\text { breadth } \\
(\mu)\end{array}$ & $\begin{array}{c}\text { Angular } \\
\text { percentage } \\
\text { unstained }\end{array}$ \\
\hline $\begin{array}{l}\text { Control mean } \\
\text { Experimental mean }\end{array}$ & - & $\begin{array}{l}22 \cdot 97 \\
21 \cdot 57\end{array}$ & $\begin{array}{l}3 \cdot 63 \\
3 \cdot 43\end{array}$ & $\begin{array}{l}14 \cdot 84 \\
13 \cdot 20\end{array}$ & $\begin{array}{l}22 \cdot 80 \\
22 \cdot 52\end{array}$ & $\begin{array}{l}0.640 \\
0.579\end{array}$ & $\begin{array}{l}49 \cdot 30 \\
47.93\end{array}$ \\
\hline $\begin{array}{l}\text { Analysis } \\
\text { Groups } \\
\text { Mice within groups } \\
\text { Slides within mice }\end{array}$ & $\begin{array}{r}1 \\
18 \\
80\end{array}$ & $\begin{array}{l}9 \cdot 11 * * * \\
0.63^{*} \\
0.32\end{array}$ & $\begin{array}{l}0.421^{* * *} \\
0.034^{* * *} \\
0.008\end{array}$ & $\begin{array}{c}12 \cdot 42^{* * * *} \\
0 \cdot 49 \\
5 \cdot 50\end{array}$ & $\begin{array}{l}0.87 \\
0.79^{* *} \\
0.356\end{array}$ & $\begin{array}{l}0.042^{* * *} \\
0.003 \\
0.002\end{array}$ & $\begin{array}{c}47 \cdot 65 \\
176 \cdot 44^{* * *} \\
33 \cdot 23\end{array}$ \\
\hline
\end{tabular}

group. On the 1st day males were treated for $4 \mathrm{hr}$ and kept away from the females. On each of the subsequent 5 days they were treated for $4 \frac{1}{2} \mathrm{hr}$ before rejoining their mates at night. The pairs were separated each morning. There were eleven repetitions of the experiment ('trials') with fresh animals for each trial.

To study the delayed effect of the treatment, the same males of the fifth, sixth and eighth to eleventh trials were paired again with virgin females for 6 days, starting 15 days after the end of treatment. Litter size was recorded in seventeen trials. 
Table 1 shows that exposure caused a decrease in the average of all spermatozoan dimensions, statistically significant for all characteristics except midpiece length and percentage of unstained spermatozoa, the mean square for mice within groups being used as error term.

For the fertility study, the mean litter size per control and experimental male was calculated, as can be worked out from Table 2, including the zero class (litter size 0 ) in the calculations. It was found that in $82.3 \pm 9.3 \%$ of the seventeen trials the experimental group had a smaller litter size than did the control. This percentage differed from the $50 \%$ of a null hypothesis at a high

TABLE 2

SUMMARY OF FERTILITY OF CONTROL AND $\mathrm{CO}_{2}$-TREATED MALES

\begin{tabular}{|c|c|c|c|c|c|}
\hline \multirow{2}{*}{$\begin{array}{l}\text { Trial } \\
\text { No. }\end{array}$} & \multirow{2}{*}{$\begin{array}{l}\text { No. of males in } \\
\text { each control } \\
\text { and experi- } \\
\text { mental group }\end{array}$} & \multicolumn{2}{|c|}{$\begin{array}{c}\text { No. of males giving a } \\
\text { litter }\end{array}$} & \multicolumn{2}{|c|}{$\begin{array}{c}\text { Mean litter size } \\
\text { (excluding litter size } 0 \text { ) }\end{array}$} \\
\hline & & Control & Experiment & Control & Experiment \\
\hline $\begin{array}{l}\text { (a) Early tests of } \\
\text { male fertility } \\
\text { I } \\
\text { II } \\
\text { III } \\
\text { IV } \\
\text { Va } \\
\text { VIa } \\
\text { VII } \\
\text { VIIIa } \\
\text { IXa } \\
\text { Xa } \\
\text { XIa }\end{array}$ & $\begin{array}{l}4 \\
3 \\
3 \\
5 \\
5 \\
5 \\
5 \\
5 \\
5 \\
5 \\
5\end{array}$ & $\begin{array}{l}4 \\
3 \\
3 \\
5 \\
3 \\
4 \\
3 \\
3 \\
4 \\
3 \\
3\end{array}$ & $\begin{array}{l}4 \\
2 \\
3 \\
3 \\
2 \\
3 \\
1 \\
2 \\
3 \\
3 \\
2\end{array}$ & $\begin{array}{r}10.00 \\
7.00 \\
8.33 \\
7.60 \\
6.00 \\
5.75 \\
7.00 \\
6.00 \\
7.25 \\
8.00 \\
7.00\end{array}$ & $\begin{array}{l}7 \cdot 75 \\
8.00 \\
9 \cdot 00 \\
9 \cdot 33 \\
7.00 \\
3.33 \\
8.00 \\
8.00 \\
9 \cdot 00 \\
3.33 \\
8.50\end{array}$ \\
\hline $\begin{array}{l}\text { (b) Delayed tests o } \\
\text { male fertility } \\
\text { Vb } \\
\text { VIb } \\
\text { VIIIb } \\
\underset{\text { IXb }}{\text { Xb }} \\
\text { XIb }\end{array}$ & $\begin{array}{l}5 \\
5 \\
5 \\
5 \\
5 \\
5\end{array}$ & $\begin{array}{l}3 \\
4 \\
4 \\
5 \\
5 \\
5\end{array}$ & $\begin{array}{l}1 \\
3 \\
4 \\
4 \\
4 \\
5\end{array}$ & $\begin{array}{l}7 \cdot 33 \\
6 \cdot 75 \\
7 \cdot 75 \\
7 \cdot 20 \\
7 \cdot 80 \\
8 \cdot 00\end{array}$ & $\begin{array}{l}5 \cdot 00 \\
7 \cdot 33 \\
6-25 \\
9 \cdot 25 \\
5 \cdot 50 \\
8 \cdot 00\end{array}$ \\
\hline
\end{tabular}

level of significance $(P<0.001)$. It was concluded that males gassed with $\mathrm{CO}_{2}$ give fewer offspring per mating than controls. When the zero class was excluded, the weighted mean difference (control-experiment) in the early test was $0.07 \pm 0.60$ offspring/litter, and $0.37 \pm 0.55$ in the delayed test; clearly, neither difference is significant. Hence the effect of gassing was on the conception rate. This is evident in Table 2, where there are twelve occasions on which the number of fertile males was less in experimental than in control groups, five occasions when the numbers were equal, and no occasions when experiment exceeded control. Analysis of a balanced factorial arrangement extracted from the original data showed significant variation $(0.05>P>0.025)$ between the conception rate of experimental and control animals.

\section{REFERENCE}

Beatty, R. A. \& Mukherjee, D. P. (1963) Spermatozoan characteristics in mice of different ages. 7. Reprod. Fert. 6, 261. 